\title{
Measurement techniques for assessing the olfactory impact of municipal sewage treatment plants
}

\author{
Jacek Gebicki • Hubert Byliński • Jacek Namieśnik
}

Received: 31 August 2015 / Accepted: 2 December 2015 /Published online: 15 December 2015

(C) The Author(s) 2015. This article is published with open access at Springerlink.com

\begin{abstract}
The study presents information about the measurement techniques used for the assessment of air quality in terms of the olfactory intensity resulting from the operation of municipal sewage treatment plants. Advantages and disadvantages of the measurement techniques used are presented. Sources of malodourous substance emission from sewage treatment plants were described, and the malodourous substances emitted were characterised. Trends in development of analysis and monitoring of the malodourous substances in the air were also presented.
\end{abstract}

Keywords Sewage treatment plants · Measurement techniques $\cdot$ Electronic nose $\cdot$ Olfactometry

\section{Introduction}

More and more attention is devoted to environmental protection issues, including atmospheric air quality, as a result of the introduction of the principles of green chemistry into the technological practice and other types

\footnotetext{
J. Gebicki $(\bowtie)$

Department of Chemical and Process Engineering, Chemical Faculty, Gdansk University of Technology, Narutowicza 11/12 Street, 80-233 Gdansk, Poland

e-mail: jacek.gebicki@pg.gda.pl

H. Byliński · J. Namieśnik

Department of Analytical Chemistry, Chemical Faculty, Gdansk University of Technology, Narutowicza 11/12 Street, 80-233 Gdansk, Poland
}

of human activity, which result from the sustainable development concept. Dynamic economic development contributes to an increased amount of pollutants emitted into the environment, which can have a negative effect on the abiotic part of the environment as well as on living organisms, human health and life. Municipal sewage treatment plants belong to the symptoms of human pressure, which can be particularly onerous (Gostelow et al. 2001; Henshaw et al. 2006; Nicell 2009; Baltrenas et al. 2013).

In a majority of currently operating treatment plants, the sewage treatment process consists of the following stages:

- Mechanical treatment-separation of all solids, floating bodies, fats and oils

- Biological treatment — processes of contaminant decomposition, which usually occur under aerobic conditions owing to microorganisms

- Biological treatment with the removal of nutrients, i.e. nitrogen and phosphorus compounds - removal of contaminants by adding various coagulants, which facilitate the nutrient precipitation process

- Water renewal - use of various processes to improve water quality, such as filtration, coagulation, osmosis and ion exchange

Amongst the sewage treatment stages listed, those related to preliminary treatment, which takes place with the use of various kinds of grilles, sand separators or initial settling tanks, where anaerobic processes occur, contribute the most to emission of malodourous 
substances (Stuetz and Frechen 2001). Air pollutant emissions from individual sources from the sewage treatment plant, which can influence the occurrence of malodour in adjacent areas, are presented in Fig. 1 (Naddeo et al. 2012; Lazarova et al. 2013).

Organic odourous compounds include, amongst other things, organic sulphur compounds, indoles, skatoles, organic acids, aldehydes and ketones. Table 1 summarises the information about olfactory sensations associated with some chemical compounds emitted from the sewage treatment plant (Gostelow et al. 2001).

As shown by research results described in the literature, the odours emitted from sewage treatment plants are not carcinogenic; however, their presence in the air often has a disadvantageous effect on people inducing such symptoms as headache and dizziness, malaise, concentration problems or other health hazards (Luginaah et al. 2000; Fransses et al. 2002; Rosenkranz and Cunningham 2003; Guillot 2012; Capelli et al. 2012). Moreover, their emission has a negative effect on the plant and animal ecosystem (Nicell 2009). The level of emission of these compounds into the environment is variable, and it largely depends on the sewage quality, rate of biological changes occurring in the collected sewage or technological solutions employed at the sewage treatment plants.

In the E.U., stricter and stricter legislative regulations are being adopted, which contain recommendations regarding levels of odour emissions from various sources. Special attention is paid to the issue of measuring concentrations and determining features (categories) of emitted odourants. The determination of individual

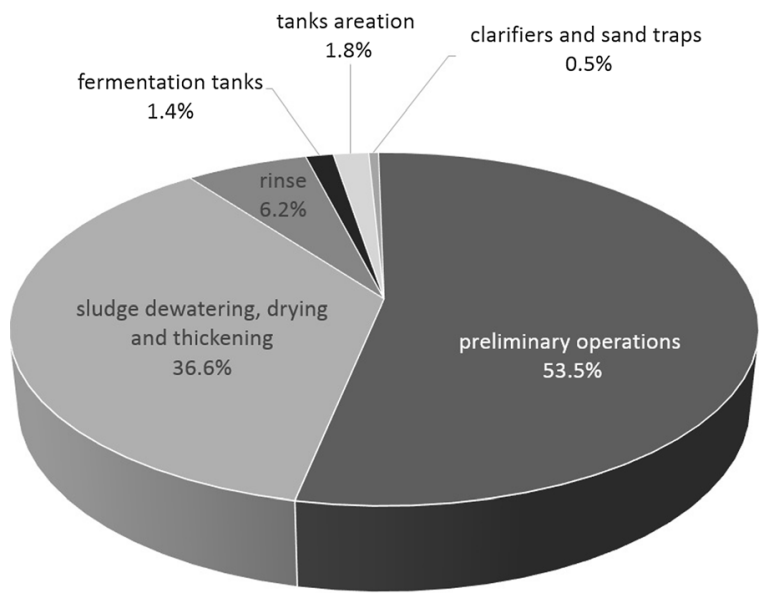

Fig. 1 Average percentage distribution of odour emission sources from a sewage treatment plant odourants in atmospheric air is necessary to determine the condition of the environment in a comprehensive manner (Belgiorno et al. 2012). Despite measurements of concentrations of emitted odours, it is often required that the route of pollution dissemination should be traced and socio-technical treatment undertaken should be assessed (treatment of gas-emitting streams, air-tight sealing of devices and installations). Appropriate tools are used for measuring and controlling the level of air pollution by various xenobiotics (de Nevers 2010).

Measurement techniques used for the assessment of atmospheric air quality in terms of odour intensity

Appropriate measurement techniques should be used to determine the level of various odourants emitted into the environment during sewage treatment plant operation or only from its individual subunits. Selection of the technique very often results from a range of factors, which, to a lesser or greater extent, may influence the final test results (variability of sample collection conditions or variability of its composition in time). It is worth emphasising that there is not one commonly accepted technique, which would allow for the effective estimation of the influence of odourous compounds on the environment (Naddeo et al. 2012).

Over the past few decades, a range of new technical and processing solutions have appeared, which have had an enormous influence on the development of research in the area of measurement of atmospheric air pollution. This progress was also related to legal aspects defining the method of conducting such research. Figure 2 presents the so-called milestones regarding the development of knowledge and technology of odour intensity measurements and development of legislation pertaining to olfactory measurements (Gohlke and McLafferty 1993; Gardner and Bartlett 1994; van Ruth 2001).

Considering the most general classification of techniques used in the assessment of the intensity of unpleasant odours, two basic approaches can be distinguished: the analytical and sensory ones. Sensory techniques, including most frequently applied dynamic olfactometry, allow determination of odour concentration (of single substance, defined odourant mixtures, non-defined odourant mixtures) of the substances present in investigated samples, odour intensity and its hedonic quality. In the case of these techniques, the human nose plays the role of the "measurement sensor" (Suffet 
Table 1 Olfactory substances emitted from a sewage treatment plant

\begin{tabular}{|c|c|c|c|}
\hline Class of compounds & Name & Molecular formula & Type of odour \\
\hline \multirow[t]{7}{*}{ Aldehydes and ketones } & Formaldehyde & $\mathrm{HCHO}$ & Pungent, stifling \\
\hline & Acetaldehyde & $\mathrm{CH}_{3} \mathrm{CHO}$ & Fruity, apple \\
\hline & Butyraldehyde & $\mathrm{C}_{3} \mathrm{H}_{7} \mathrm{CHO}$ & Rancid, odour of sweat \\
\hline & Isobutyl aldehyde & $\left(\mathrm{CH}_{3}\right)_{2} \mathrm{CHCHO}$ & Fruity \\
\hline & Isovaleric aldehyde & $\left(\mathrm{CH}_{3}\right)_{2} \mathrm{CHCH}_{2} \mathrm{CHO}$ & Fruity, apple \\
\hline & Acetone & $\mathrm{CH}_{3} \mathrm{COCH}_{3}$ & Fruity, sweet \\
\hline & Butanone & $\mathrm{C}_{2} \mathrm{H}_{5} \mathrm{COCH}_{3}$ & Apple \\
\hline \multirow[t]{3}{*}{ Carboxylic acids } & Acetic acid & $\mathrm{CH}_{3} \mathrm{COOH}$ & Vinegar \\
\hline & Butanoic acid & $\mathrm{C}_{3} \mathrm{H}_{7} \mathrm{COOH}$ & Rancid, odour of sweat \\
\hline & $n$-Pentanoic acid & $\mathrm{C}_{4} \mathrm{H}_{9} \mathrm{COOH}$ & Odour of sweat \\
\hline \multirow[t]{9}{*}{ Nitrogen compounds } & Ammonia & $\mathrm{NH}_{3}$ & Sharp, pungent \\
\hline & Methylamine & $\mathrm{CH}_{3} \mathrm{NH}_{2}$ & Fish \\
\hline & Dimethylamine & $\left(\mathrm{CH}_{3}\right)_{2} \mathrm{NH}$ & Fish \\
\hline & Trimethylamine & $\left(\mathrm{CH}_{3}\right)_{3} \mathrm{~N}$ & Fish, pungent \\
\hline & Ethylamine & $\mathrm{C}_{2} \mathrm{H}_{5} \mathrm{NH}_{2}$ & Pungent \\
\hline & Ethylenediamine & $\mathrm{NH}_{2}\left(\mathrm{CH}_{2}\right)_{5} \mathrm{NH}_{2}$ & Rotten meat \\
\hline & Pyridine & $\mathrm{C}_{6} \mathrm{H}_{5} \mathrm{~N}$ & Unpleasant, irritant \\
\hline & Indole & $\mathrm{C}_{8} \mathrm{H}_{6} \mathrm{NH}$ & Odour of faeces, mucilaginous \\
\hline & Skatole & $\mathrm{C}_{9} \mathrm{H}_{8} \mathrm{NH}$ & Odour of faeces, mucilaginous \\
\hline \multirow[t]{18}{*}{ Sulphur compounds } & Hydrogen sulphide & $\mathrm{H}_{2} \mathrm{~S}$ & Rotten eggs \\
\hline & Dimethyl sulphide & $\left(\mathrm{CH}_{3}\right)_{2} \mathrm{~S}$ & Rotten vegetables, garlic \\
\hline & Diethyl sulphide & $\left(\mathrm{C}_{2} \mathrm{H}_{5}\right)_{2} \mathrm{~S}$ & Mucilaginous \\
\hline & Diphenyl sulphide & $\left(\mathrm{C}_{6} \mathrm{H}_{5}\right)_{2} \mathrm{~S}$ & Burnt rubber \\
\hline & Allyl sulphide & $\left(\mathrm{CH}_{2} \mathrm{CHCH}_{2}\right)_{2} \mathrm{~S}$ & Garlic \\
\hline & Carbon disulphide & $\mathrm{CS}_{2}$ & Rotten vegetables \\
\hline & Dimethyl disulphide & $\left(\mathrm{CH}_{3}\right)_{2} \mathrm{~S}_{2}$ & Rotten eggs \\
\hline & Methanethiol & $\mathrm{CH}_{3} \mathrm{SH}$ & Rotten cabbage, garlic \\
\hline & Ethanethiol & $\mathrm{C}_{2} \mathrm{H}_{5} \mathrm{SH}$ & Rotten cabbage \\
\hline & Propanethiol & $\mathrm{C}_{3} \mathrm{H}_{7} \mathrm{SH}$ & Unpleasant \\
\hline & Butyl mercaptan & $\mathrm{C}_{4} \mathrm{H}_{9} \mathrm{SH}$ & Unpleasant \\
\hline & Tert-butyl mercaptan & $\left(\mathrm{CH}_{3}\right)_{3} \mathrm{CSH}$ & Unpleasant \\
\hline & Allyl mercaptan & $\mathrm{CH}_{2} \mathrm{CHCH}_{2} \mathrm{SH}$ & Garlic \\
\hline & Crotyl mercaptan & $\mathrm{CH}_{3} \mathrm{CHCHCH}_{2} \mathrm{SH}$ & Rancid \\
\hline & Benzyl mercaptan & $\mathrm{C}_{6} \mathrm{H}_{5} \mathrm{CH}_{2} \mathrm{SH}$ & Rancid \\
\hline & Thiocresol & $\begin{array}{l}\mathrm{CH}_{3} \mathrm{C}_{6} \mathrm{H}_{4} \mathrm{SH} \\
\mathrm{C}_{6} \mathrm{H}_{4} \mathrm{SH}\end{array}$ & Rancid \\
\hline & Thiophenol & $\mathrm{C}_{6} \mathrm{H}_{5} \mathrm{SH}$ & \\
\hline & Sulphur dioxide & $\mathrm{SO}_{2}$ & Rotten vegetables, mucilaginous \\
\hline
\end{tabular}

and Rosenfeld 2007; Munoz et al. 2010; Capelli et al. 2010; Guillot et al. 2012).

However, if a slight change in the emission of a single odourous substance has an enormous influence on the total emission resulting from the activity of a specific facility, e.g. sewage treatment plant, the analytical techniques become more advantageous than the sensory methods, as they allow for determining 


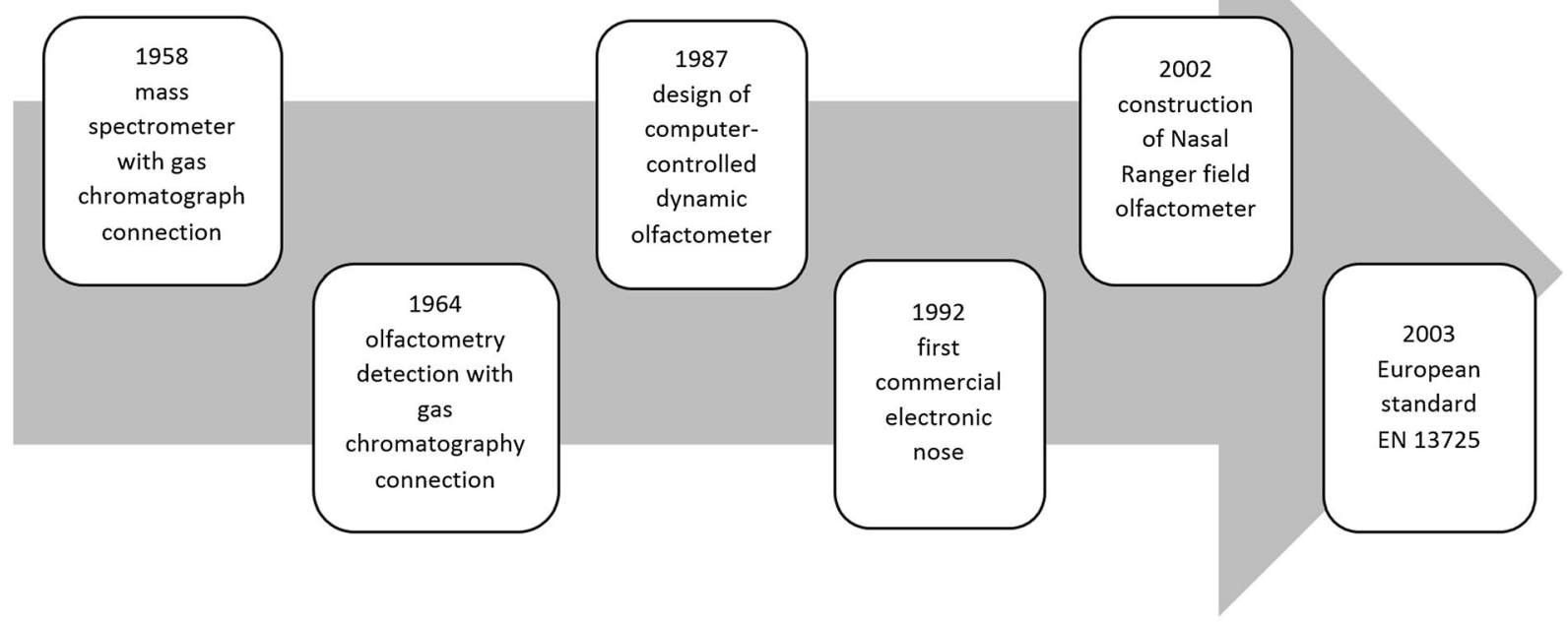

Fig. 2 Milestones in the development of odour intensity measurement techniques

concentrations of individual components of the malodourous mixture ( Schwarzenbach et al. 2003; Nagaraj and Sattler 2005).

These techniques are mostly used for the identification and quantitative analysis of malodourous chemical compounds emitted into the environment. They are based on the characterisation of a given sample by accurate determination of its chemical composition. (Brattoli et al. 2011). They are distinguished by high repeatability, objectivity and accuracy (Zarra et al. 2009).

Figure 3 presents a diagram with a classification of the most important techniques, which are used to assess air quality in terms of odour intensity.

Gas chromatography with olfactometric detection (GC-O)

GC-O allows for sensory assessment of compounds, which are released from the chromatographic column, together with an eluent stream. The human nose plays the role of an additional detector. Therefore, it is necessary to have a team of persons assessing the smell, just like in dynamic olfactometry. For each substance present in the analysed mixture, it is possible to perform quantitative and qualitative analysis simultaneously, i.e. stating whether a given compound can be sensorically detected at a strictly specified concentration, specifying what odour it has and determining the sensory intensity and the time of olfactory activity (Ferreira et al. 2002;
Boudhrioua et al. 2003; Ferrari et al. 2004; Frank et al. 2004; Kleeberg et al. 2005; Bulliner et al. 2006; Zhang et al. 2010).

Figure 4 presents a diagram of a gas chromatograph design combined with an olfactometry detector. It is possible to assess the olfactory intensity of compounds eluted from the chromatography column, thanks to the presence of a specially constructed attachment, the socalled olfactometry stub nozzle, which fulfils the role of an additional detector (apart from it, the instruments also include a detector typical of gas chromatography - this is usually a flame ionisation detector or mass spectrometry detector). The eluate stream leaving the column is divided into two separate ones to make it possible for them to reach both detectors, which allows comparison of the obtained signals. This technique can be used to identify individual components of many complex odourous mixtures. The presence of, for example, a flame ionisation detector (FID), which is commonly used for GC, makes it possible to perform also qualitative and quantitative analyses of the determined compounds, in addition to GC (Plutowska and Wardencki 2008).

Gas chromatography coupled with mass spectrometer (GC-MS)

One of the instrumental techniques for sensory analysis is certainly GC-MS. It is more and more commonly used in air pollution tests (Davoli et al. 2003; Dincer 


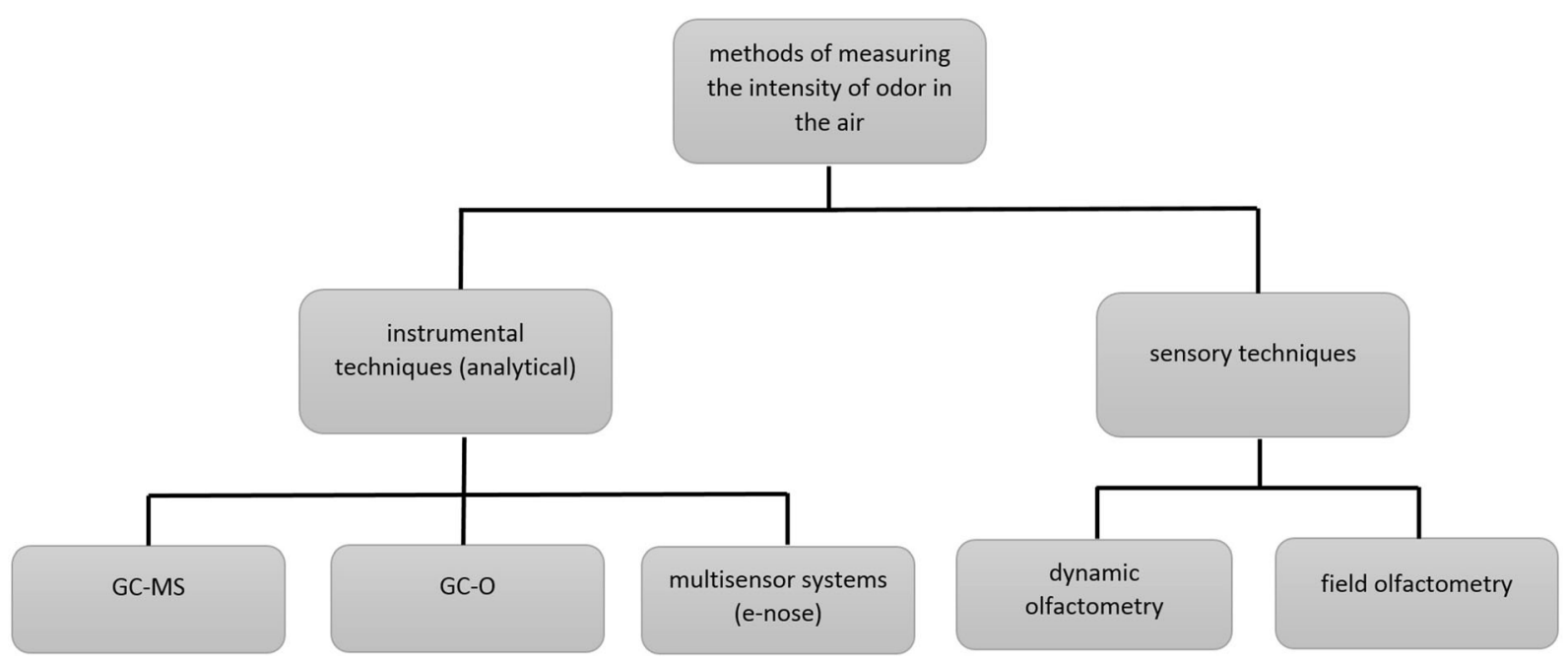

Fig. 3 Classification of techniques for air quality assessment in terms of odour intensity

et al. 2006). Its use is advantageous especially for the determination of volatile organic compounds (VOCs) and volatile sulphur compounds, which constitute an important group of odours emitted from the sewage treatment plant (Zarra et al. 2008b, 2009). This technique also works very well in the case of identification of single odourous compounds present in very complex gas mixtures (Su et al. 2008; Pandey and Kim 2009; Woolfenden 2010a, b). For this reason, it gains increasing popularity in the air tests focusing on the assessment of olfactory quality, which is influenced by various manifestations of human activity, such as landfills or municipal sewage treatment plants (Defoer et al. 2002; Cadena et al. 2009).

Basic limitations of this technique are connected with too low concentration of some compounds present in odourous mixtures - it can often be lower than the limit of detection, which makes their analysis impossible (Staley et al. 2006). In recent years, the combination of

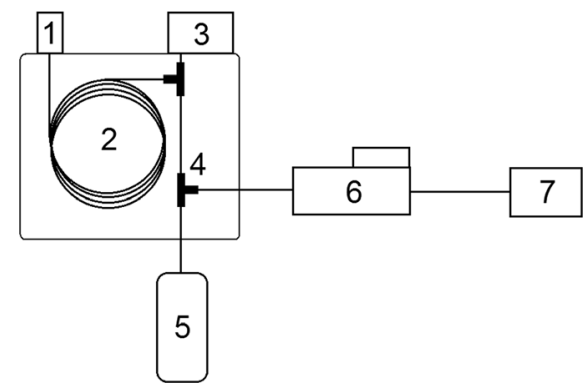

Fig. 4 The design of the gas chromatograph with olfactometric detection. 1 dispenser, 2 chromatographic column, 3 detector, 4 stream divider, 5 humid air, 6 olfactometric detector, 7 signal generator the GC-MS technique with olfactometry detection (GCMS-O) has been observed. Such a combination also allows more accurate determination of olfactory properties of individual compounds contained in mixtures (van Ruth 2001; Lo et al. 2008). That combination also makes it possible to better understand a correlation between the results of quantitative and qualitative analysis and olfactory properties of individual odourants. This approach is more and more broadly used in environmental tests, amongst other things (Brattoli et al. 2014).

Electronic nose (e-nose)

An electronic nose is a measuring device, which is used for the sensory assessment of many chemical compounds from various sources. This device works in a manner similar to the human sense of smell. Odourous compounds are usually detected in it owing to the presence of a set of non-specific chemical sensors. However, its possibilities are much smaller than those of its "biological counterpart", for example, due to the necessity of using a complex mathematical apparatus, which is responsible for proper interpretation of results (Rock et al. 2008; Wilson and Baietto 2009; Sankaran et al. 2012; Gebicki et al. 2014a, b; Boeker 2014).

Figure 5 presents a diagram with the principle of electronic nose operation. The most important components of the relevant measurement system include:

- A sample collection system

- A system of sensors 


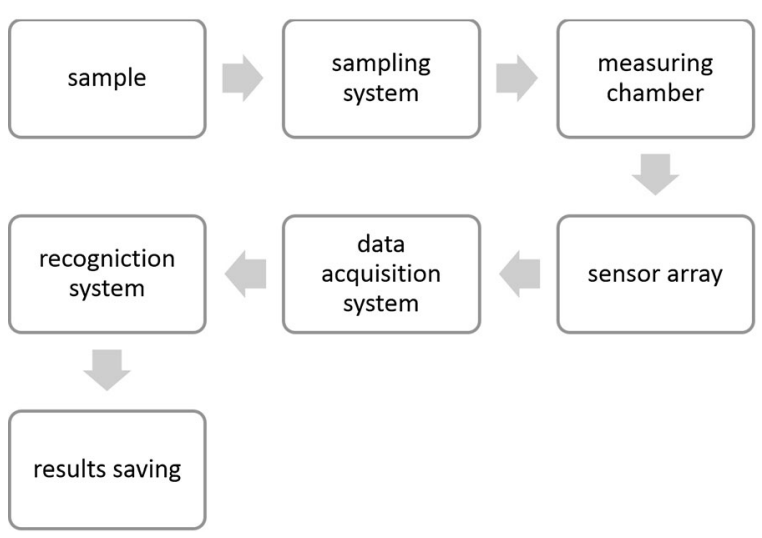

Fig. 5 Diagram of e-nose operation

- Data collection system

- Recognition system

A design of the sample collection system is aimed at ensuring the possibility of eliminating all undesirable factors, which can influence the response of the detector (Dymerski et al. 2011). The majority of currently available devices have two chambers in this system: the sensor chamber and the sample chamber. They are monitored during analyses in terms of temperature and humidity level (Hodgins 1995; Patel 2014). The sensor system makes it possible to measure desired properties - with variable selectivity. The data collection system is responsible for processing the data obtained during measurements and recording them in an appropriate form, whilst the recognition system is responsible for qualitative identification of odourous substances on the basis of comparing the olfactory profile of the sample with the reference profile in the database (Boholt et al. 2005; Micone and Guy 2007; Delgado-Rodríguez et al. 2012). The electronic noses allow for conducting "continuous" field tests as they do not exhibit, as opposed to the human nose, olfactory adaptation (Nicolas and Romain 2004; Giuliani et al. 2012); therefore, they are more and more often used for the assessment of environmental pollution. In this way, it is also possible to register small changes in concentration of a given substance in the tested gas medium (Romain et al. 2005; Szczurek and Maciejewska 2005; Sohn et al. 2006; Bootsma et al. 2014).

\section{Dynamic olfactometry}

Dynamic olfactometry is a standardised measurement technique. It is preferred and, at the same time, most often used in the E.U. countries to determine concentration of individual odourants in mixtures of odourous substances emitted into the environment from various sources, also including municipal sewage treatment plants (Sironi et al. 2010; Belgiorno et al. 2012). Figure 6 presents a diagram of a research station design used for olfactometric measurements. These analyses are based on mixing a gas sample containing olfactory compounds with odourless neutral gas at specific ratios. The most frequently used olfactometers are equipped with four stations, which allows simultaneous presentation of a series of dilutions to more than one person. A panel of persons assessing the odour of the tested sample takes part in olfactometric tests. Such persons must receive prior training in terms of sensing even slight changes in olfactory intensity. Requirements for the persons participating in that type of research are contained in the standard EN 13725:2003 "Air quality. Determination of odour concentration by dynamic olfactometry." The standard also contains, amongst other things, the procedure for odour determination using dynamic olfactometry, the sample collection techniques and the information about the method of obtained data recording and interpretation.

The results of measurements obtained using the dynamic olfactometry method are expressed in the European Odour Unit $\left[1 \mathrm{ou}_{\mathrm{E}} / \mathrm{m}^{3}\right]$. This unit is defined as the quantity of the odourant or odourants, which after evaporation to neutral gas of $1 \mathrm{~m}^{3}$ volume under normal conditions induces a physiological reaction in the members of the assessment team, which is equivalent to that resulting from the European Reference Odour Mass (EROM) odour reference, which has also been evaporated to $1 \mathrm{~m}^{3}$ of neutral gas under standard conditions. Standard conditions, which are referred to in the definition above, are consistent with the ISO 10780 , i.e.:

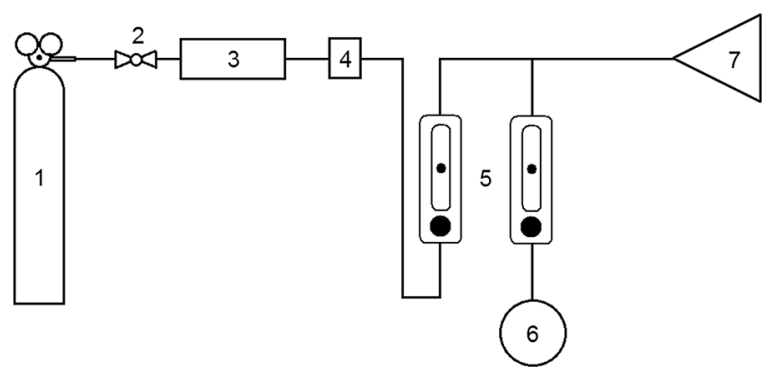

Fig. 6 Diagram of a station for measuring olfactory intensity using the dynamic olfactometry technique. 1 cylinder with odourless air, 2 valve, 3 filter, 4 microfilter, 5 rotameters, 6 gas sample under analysis, 7 smelling mask 
- Room temperature-298.15 K

- Atmospheric pressure-101,325 Pa

Determination of odourant concentrations using dynamic olfactometry very often involves high costs connected with the preparation of a specialist olfactometric laboratory and ensuring that people who take part in tests have an olfactory sensitivity monitored on a regular basis.

The results obtained from this technique, especially for low concentrations of individual odourants, can considerably diverge from actual ones due to the possibility of changing the chemical composition of the sample between the time of its collection and the time of the analysis. Therefore, these tests are mostly recommended for determining olfactory compounds with high concentrations, much higher than emission ones, which occur in atmospheric air.

In many E.U. countries, the attempts have been made to introduce legal acts regulating olfactory pollution emissions. They define, amongst other things, admissible emissions of odourant concentrations in the environment and the procedure for measuring them. Due to changing conditions of urban infrastructure and the related increase in pollutants concentrations, it is necessary to update and further develop the recommendations contained in relevant legal acts, which takes place in many countries, both in Europe and in the world. The related procedures are time-consuming but, despite this, an increasing progress is observed in the legislation concerning environmental protection. Table 2 summarises the information about the most important legal regulations concerning prevention of olfactory onerousness.

\section{Field olfactometry (FO)}

The tools used for the assessment of odourous substances released into the environment include field olfactometers, which allow for in situ testing of concentration of odourous substances and odour emissions. These devices are portable so test results can be obtained in real time; the team of assessing persons defines the odour of substances in analysed samples. Field test results make it possible to identify sources of odourants and also to estimate the total odour emissions at a given measurement point. Environmental olfactometry is also used for the assessment of the degree of onerousness, the frequency of occurrence and the influence of odours
Table 2 Selected legal acts in force in various countries, which concern the prevention of olfactory onerousness

\begin{tabular}{|c|c|}
\hline Country & Legal act \\
\hline Netherlands & $\begin{array}{l}2000 \text {-Nederlandse Emissie Richtlijnen NeR, } \\
\text { Nederlandse Emissie-richtlijn Lucht } \$ 3.6(\mathrm{NeR}) \text { : } \\
\text { Handleiding geur: Bepalen van het aanvaardbare } \\
\text { hinderniveau van industrie en bedrijven (niet } \\
\text { ve-ehouderijen) }\end{array}$ \\
\hline \multirow[t]{3}{*}{ Germany } & $\begin{array}{l}\text { 1986_-VDI } 3881 \text { Olfactometry: Odour Threshold } \\
\text { Determination }\end{array}$ \\
\hline & $\begin{array}{l}1994 \text {-Feststellung und Beurteilung von } \\
\text { Geruchsimmissionen-Geruchsimmssions- } \\
\text { Richtlinie (GIRL) }\end{array}$ \\
\hline & $\begin{array}{l}\text { 2008_-Feststellung und Beurteilung von } \\
\text { Geruchsimmissionen-Geruchsimmssions- } \\
\text { Richtlinie (GIRL) }\end{array}$ \\
\hline \multirow{2}{*}{$\begin{array}{l}\text { Great } \\
\text { Britain }\end{array}$} & 1990 -Environmental Protection Act-EPA \\
\hline & $\begin{array}{l}\text { 2003-Technical Guidance Note IPPC H4 } \\
\text { Horizontal Guidance for Odour }\end{array}$ \\
\hline Japan & 1972-The Offensive Odor Control Law in Japan \\
\hline Denmark & 2008 - Dutch Legislation on Ammonia and Odour \\
\hline $\begin{array}{l}\text { North } \\
\text { Korea }\end{array}$ & 2005-New Odour Prevention Act \\
\hline
\end{tabular}

on the comfort of living of inhabitants in a given area. The use of olfactometric techniques is connected with the necessity of having an experienced team of assessing persons, whose sensory sensitivity can be reduced due to various factors (Both et al. 2004).

The diagram of the field olfactometer design is presented in Fig. 7. This type of device is a kind of a gas mask equipped with a filter with activated carbon. At the beginning, the assessing person inhales clean air, purified on a filter, and, after a minute, gradually increases the share of the air collected from the environment and bypassing the activated carbon filter. The aim of the tests is determination of the numerical value of the dilution-

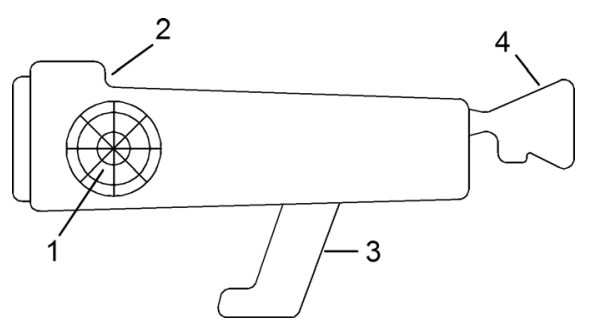

Fig. 7 Diagram of field olfactometer design. 1 activated carbon filter, 2 electronic display of measurement results, 3 handle, 4 replaceable mouth and nose mask 
to-threshold $(D / T)$ ratio parameter, at which the odour of the gas mixture can be smelled by the assessing person.

However, no technical parameters have been defined for the research conducted using field olfactometry. No quality parameters or criteria concerning accuracy and precision have been determined. The results obtained can be considerably influenced by errors connected with variable perception or faulty operation of activated carbon filters. However, FO is more and more commonly used in the assessment of odour onerousness, which results from the activity of various facilities, including municipal engineering plants (Smeets et al. 2007; Capelli et al. 2011).

Table 3 presents the information, which can constitute the basis for a critical comparison of the measurement techniques used for the assessment of atmospheric air quality in terms of olfactory intensity (Nagy 1991; Hobbs et al. 1995; Di Francesco et al. 2001; Arshak et al. 2004; Rosenfeld et al. 2004; Bulliner et al. 2006; Sohn et al. 2008; Munoz et al. 2010; Zhang et al. 2010; Sówka 2010; Brattoli et al. 2011; Sówka et al. 2011; Le et al. 2013; Vergara et al. 2013; Dymerski et al. 2014).

\section{Exemplary information about the measurement} techniques used in the assessment of atmospheric air quality in terms of odour intensity in a sewage treatment plant

Table 4 presents the information about the measurement techniques used for the assessment of atmospheric air quality in terms of odour intensity.

\section{Trends in development of analysis and monitoring of malodourous substances in the air}

Legislative bodies in the majority of developed countries undertake the problem of regulating admissible olfactory pollutant emission (Henshaw et al. 2006; Nicell 2009; Bokowa 2010). In many countries, the regulations pertaining to odour emissions are continuously changed and improved. The electronic noses are beginning to be accepted as the devices used in reference methodologies to measure odours (Engg and College 2013). For example, in France (BarriadaPereira et al. 2010), new regulations make it possible to use the e-noses to monitor odours from sewage waste neutralisation processes (rendering) and composting. On-line monitoring is possible with the use of one or several e-noses at the distances regulated by the act.
Also, the frequency of measurements performed with the electronic nose is specified by the act. Due to the specificity of electronic nose operation, these devices can successfully complement current odour measurement techniques and such improvements are treated very seriously in many countries in the world. The effectiveness of introduced legal solutions is confirmed by decreasing number of complaints, which means that the impact of odour-related onerousness on communities inhabiting the areas around the main emitters is reduced (Loriato et al. 2012).

The electronic nose can be used as a device complementing other analytical techniques, namely sensory analysis techniques. At present, the devices allowing for analysing odours and controlling admissible concentrations of malodourous substances are available on the market. Moreover, work on improvement of these devices is in progress and new better versions of their prototypes are developed. One of the basic problems related to sensors is their stability during temperature and humidity changes as well as sensor response drift in time. In recently published studies, Dentoni et al. (2012) describe an innovative electronic nose developed for monitoring of the environment, which includes solutions for signal drift compensation and for sample humidity regulation. Challenges concerning the use of electronic noses in environmental monitoring should not focus only on the development of new sensors or data processing methods, but they should rather concentrate on the adaptation of existing devices to external applications. In the years to come, possibilities of using the electronic noses under real conditions as portable devices for controlling outdoor air should become more popular (Capelli et al. 2013).

The most critical aspect limiting the use of electronic noses is the lack of specific regulations for their standardisation. As mentioned above, the electronic noses for environmental monitoring are complex devices and the way, in which they are used, is connected with high diversity, especially as regards the training and data processing stages. The actual standardisation of the devices in terms of their proper use and objectification of tests performed, which is aimed at simplification and unification of the stages of analysis, can contribute to popularisation of such an instrument for environmental applications in the future. One of the first attempts at the standardisation of outdoor air measurements using the electronic nose was presented by a Dutch 
Table 3 Comparison of measurement techniques used for the assessment of atmospheric air quality in terms of odour intensity

\begin{tabular}{|c|c|c|c|}
\hline Method of analysis & Method of analysis & Advantages & Disadvantages \\
\hline $\begin{array}{l}\text { Analytical methods } \\
\text { (e.g. GC-MS) }\end{array}$ & $\begin{array}{l}\text { Samples collected at emission } \\
\text { sources, next analysed using } \\
\text { various detectors, e.g. MS }\end{array}$ & $\begin{array}{l}\text { Possibility of accurate assessment } \\
\text { of the content of individual } \\
\text { analytes in the mixture, } \\
\text { significant from the legislative } \\
\text { perspective. Owing to high } \\
\text { resolution, it is possible to identify } \\
\text { the origin of compounds, and it is } \\
\text { helpful when several emission } \\
\text { sources occur } \\
\text { Sample concentration is sometimes } \\
\text { required }\end{array}$ & $\begin{array}{l}\text { Sensory assessment of a sample is not } \\
\text { possible, and sample } \\
\text { representativeness and integrity } \\
\text { depend on many factors, e.g. the } \\
\text { type of container, collection time etc. } \\
\text { The majority of methods does not } \\
\text { allow for gas analysis at the human } \\
\text { nose level } \\
\text { Expensive and labour intensive }\end{array}$ \\
\hline GC-MS-O & $\begin{array}{l}\text { As above, except for the fact } \\
\text { that a half of the flowing } \\
\text { sample after separation is } \\
\text { directed to a person in the } \\
\text { sensory panel }\end{array}$ & $\begin{array}{l}\text { Additional significant human factor } \\
\text { Cross-tables with results between } \\
\text { the MS detector and olfactometry } \\
\text { can provide new information } \\
\text { about the contribution of single } \\
\text { odourants to the odour of the } \\
\text { entire mixture }\end{array}$ & $\begin{array}{l}\text { Due to the separation of analytes in the } \\
\text { GC system, odourous substances } \\
\text { cannot be analysed together, } \\
\text { potential synergistic or antagonistic } \\
\text { effects cannot be assessed } \\
\text { High dependence between the } \\
\text { composition and the } \\
\text { representativeness and integrity of } \\
\text { the sample }\end{array}$ \\
\hline Electronic noses & $\begin{array}{l}\text { Devices consisting of a matrix } \\
\text { of sensors and an appropriate } \\
\text { data processing system }\end{array}$ & $\begin{array}{l}\text { Identification of odour markers at a } \\
\text { lower level than in some } \\
\text { analytical methods, e.g. using } \\
\text { photoionization detection } \\
\text { Possibility to skip the sample } \\
\text { collection stage, on-site measurement } \\
\text { Possibility of measuring odours at } \\
\text { places, which are difficult to reach }\end{array}$ & $\begin{array}{l}\text { Identification of odours at a lower level } \\
\text { than in olfactometry, which } \\
\text { influences the ability to assess the } \\
\text { impact of the odour } \\
\text { Selected sensors are sensitive only to } \\
\text { specific substances, other unknown } \\
\text { substances are no longer identified } \\
\text { Complicated calibration, necessity for } \\
\text { training, e.g. by correlation with } \\
\text { olfactometric results to assess the } \\
\text { offensive quality of odours }\end{array}$ \\
\hline $\begin{array}{c}\text { Olfactometric } \\
\text { techniques }\end{array}$ & $\begin{array}{l}\text { Main methods of measurement } \\
\text { using sensory panels of field } \\
\text { olfactometers, e.g. Nasal } \\
\text { ranger, odour detection and } \\
\text { assessment is based on the } \\
\text { sense of smell. }\end{array}$ & $\begin{array}{l}\text { Elimination of the problem of sample } \\
\text { representativeness and integrity in } \\
\text { the case of field olfactometry } \\
\text { Useful in the assessment of olfactory } \\
\text { onerousness }\end{array}$ & $\begin{array}{l}\text { Various factors influencing odour } \\
\text { assessment by panel members } \\
\text { Training is required to ensure the } \\
\text { objectivity of panel members, high } \\
\text { costs } \\
\text { Differences in odour assessment by } \\
\text { sensory panel members } \\
\text { Underestimation of olfactory } \\
\text { onerousness for the community }\end{array}$ \\
\hline
\end{tabular}

standardisation institute in the form of the NTA-9055 document.

\section{Summary}

Due to the issue of odour onerousness, which has not been regulated yet in many countries in the world, a basic step for this purpose includes objectification of the assessment of odour impact and odour limits. Individual odours can cause a broad spectrum of sensations, and the influence of an odour on odour onerousness may result from a few of its characteristic features defined by the FIDOL acronym (Loriato et al. 2012):

- Frequency of the odour occurrence

- Intensity

- Duration of the exposure

- Offensiveness of the odour, subjective

- Location of the odour

One of main problems connected with the smell is the issue of the person's exposure time to unpleasant 
Table 4 Measurement techniques used for the assessment of atmospheric air quality in terms of odour intensity

\begin{tabular}{|c|c|c|}
\hline Determined substances & Measurement technique used & References \\
\hline \multirow[t]{19}{*}{ Volatile organic compounds } & \multirow[t]{8}{*}{ Electronic nose } & Stuetz et al. (1999a) \\
\hline & & Bourgeois and Stuetz (2000) \\
\hline & & Dewettinck et al. (2001) \\
\hline & & Bourgeois and Stuetz (2002) \\
\hline & & Bourgeois et al. (2003a) \\
\hline & & Bourgeois et al. (2003b) \\
\hline & & Onkal-Engin et al. (2005) \\
\hline & & Guz et al. (2015) \\
\hline & \multirow[t]{3}{*}{ Electronic nose, olfactometry } & Stuetz et al. (1998) \\
\hline & & Littarru (2007) \\
\hline & & Capelli et al. (2008) \\
\hline & \multirow[t]{3}{*}{ GC-MS } & Escalas et al. (2003) \\
\hline & & Wu et al. (2006) \\
\hline & & Zarra et al. (2008a) \\
\hline & \multirow[t]{4}{*}{ Olfactometry } & Gostelow et al. (2001) \\
\hline & & Suffet et al. (2004) \\
\hline & & Suffet and Rosenfeld (2007) \\
\hline & & Capelli et al. (2009) \\
\hline & Electronic nose, GC-MS, olfactometry & Zarra et al. (2014) \\
\hline \multirow[t]{2}{*}{$\mathrm{H}_{2} \mathrm{~S}$} & Electronic nose, olfactometry & Stuetz et al. (1999b) \\
\hline & Olfactometry & Dincer and Muezzinoglu (2007) \\
\hline $\mathrm{CH}_{3} \mathrm{SH}$ & Electronic nose & Nake et al. (2005) \\
\hline \multirow[t]{4}{*}{ Organic sulphur compounds } & \multirow[t]{3}{*}{ GC-MS } & Cheng et al. (2007) \\
\hline & & Ras et al. (2008) \\
\hline & & Sheng et al. (2008) \\
\hline & Olfactometry, GC-MS & Rajbansi et al. (2014) \\
\hline \multirow[t]{9}{*}{ Volatile organic compounds and organic sulphur compounds } & GC-MS & Godayol et al. (2011) \\
\hline & GC-MS-O & Ranau et al. (2005) \\
\hline & \multirow[t]{2}{*}{ GC-MS, olfactometry } & Zarra et al. (2008b) \\
\hline & & Zarra et al. (2009) \\
\hline & \multirow[t]{5}{*}{ Olfactometry } & Barczak et al. (2012) \\
\hline & & Naddeo et al. (2012) \\
\hline & & Zarra et al. (2012) \\
\hline & & Almarcha et al. (2014) \\
\hline & & Baltrenas et al. (2013) \\
\hline Sulphur and nitrogen odourants & GC-MS & Turkmen et al. (2004) \\
\hline Sulphur, nitrogen odourants and volatile organic compounds & GC-MS, GC-O & Agus et al. (2012) \\
\hline
\end{tabular}

odours, which does not cause onerousness. It can be assumed that there exist two concepts, which allow for minimising this problem-limiting the odour emission level so that it is not detected all the time or releasing odours periodically at higher concentration on a shortterm basis, owing to which the exposure can be reduced. 
To prevent air quality deterioration, emission odour standards have been determined in many countries in the world, which use:

- The odour unit allowing for defining the concentration of individual odourants or their mixture in a specific manner $\left(c_{\mathrm{od}}\left[\mathrm{ou}_{\mathrm{E}} / \mathrm{m}^{3}\right]\right)$

- Standards pertaining to odour emissions ( $\left.q_{\text {od }}[\mathrm{ou} / \mathrm{h}]\right)$

- Diagrams of minimal distances of sources of emissions from residential buildings

- Analysis of complaints concerning odours

In the assessment of the degree of the intensity of the impact of unpleasant smells, the odour unit is most often used, which is defined as the quantity of the odourant and/or odourants, which induces a physiological reaction of the assessing team (odour threshold value) after evaporating a cubic metre of gas under standard conditions by a representative group of people, the so-called sensory panel. A popular method of assessing the degree of odour impact is the use of mathematical models to predict the level of odour dispersion after taking into account the wind rose, size of emission source, terrain topography and meteorological data. Owing to the use of the dilution of an atmospheric air sample to its odour threshold value ( $D / T$ counterpart of $\left.c_{\mathrm{OD}}\right)$, it is possible to perform quantitative and qualitative analysis of odours or their mixtures in accordance with the methods contained in relevant standards (e.g. ASTM Method E679-04 or European Method EN 13725:2003).

A lot of classical methods for determining malodourous substances are considered to be too expensive to create commonly available measuring instruments or develop environmental monitoring systems. High hopes for the development of such systems are placed on sensor techniques. Odour analysis is more and more frequently performed with the use of electronic noses. Despite the low applicability of these devices for the monitoring of air pollution as compared with olfactometry, their application is growing. The stages of selecting appropriate sensors and data processing method make it possible to use electronic noses for the analysis of odours of various origins. One of the main advantages of these devices is the possibility of skipping the first stage of sample preparation for the analysis and the possibility of their field use as a portable unit to monitor emission sources in real time. Numerous literature reports, which are devoted to theoretical fundamentals of electronic nose operation and practical possibilities of their use, are the basis for concluding that the development of odour analysis is connected with the use of electronic noses. The authors of the article hope that the reference methods in the analysis of malodourous substances will soon be extended in many countries to include the possibility of using the electronic nose. Such devices would be an element of early warning against sudden odour hazards. For shortterm odour onerousness, it will be possible to register them using the e-nose, which, in turn, is often not possible after qualified personnel arrives on site to perform field olfactometry measurements. Furthermore, there are situations in which the performance of field olfactometry measurements might constitute a health hazard for people.

Open Access This article is distributed under the terms of the Creative Commons Attribution 4.0 International License (http:// creativecommons.org/licenses/by/4.0/), which permits unrestricted use, distribution, and reproduction in any medium, provided you give appropriate credit to the original author(s) and the source, provide a link to the Creative Commons license, and indicate if changes were made.

\section{References}

Agus, E., Zhang, L., \& Sedlak, D. L. (2012). A framework for identifying characteristic odor compounds in municipal wastewater effluent. Water Research, 46, 5970-5980.

Almarcha, D., Almarcha, M., Nadal, S., \& Poulssen, A. (2014). Assessment of odour and VOC depuration efficiency of advanced biofilters in rendering, sludge composting and waste water treatment plants. Chemical Engineering Transactions, 40, 223-228.

Arshak, K., Moore, E., Lyons, G. M., Harris, J., \& Clifford, S. (2004). A review of gas sensors employed in electronic nose applications. Sensor Review, 24, 181-198.

Baltrenas, P., Andrulevicius, L., \& Zuokaite, E. (2013). Application of dynamic olfactometry to determine odor concentrations in ambient air. Polish Journal of Environmental Studies, 22, 331-336.

Barczak, R., Kulig, A., \& Szyłak-Szydłowski, M. (2012). Olfactometric methods application for odour nuisance assessment of wastewater treatment facilities in Poland. Chemical Engineering Transactions, 30, 187-192.

Barriada-Pereira, M., Serodio, P., Gonzalez-Castro, M. J., \& Nogueira, J. M. F. (2010). Determination of organochlorine pesticides in vegetable matrices by stir bar sorptive extraction with liquid desorption and large volume injection-gas chromatography-mass spectrometry towards compliance with European Union directives. Journal of Chromatography A, 1217, 119-126.

Belgiorno, V., Naddeo, V., \& Zarra, T. (2012). Odour impact assessment handbook. Hoboken: Wiley. 
Boeker, P. (2014). On 'electronic nose' methodology. Sensors and Actuators B Chemical, 204, 2-17.

Boholt, K., Andreasen, K., Den Berg, F., \& Hansen, T. (2005). A new method for measuring emission of odour from a rendering plant using the Danish Odour Sensor System (DOSS) artificial nose. Sensors and Actuators B Chemical, 106, 170176.

Bokowa, A. H. (2010). Review of odour legislation. Chemical Engineering Transactions, 23, 31-36.

Bootsma, S., Leuwerink, T., \& Bilsen, I. (2014). Online air monitoring with enoses at the tata steel plant in the Netherlands. Chemical Engineering Transactions, 40, 79-84.

Both, R., Sucker, K., Winneke, G., \& Koch, E. (2004). Odour intensity and hedonic tone-important parameters to describe odour annoyance to residents. Water Science and Technology, 50, 83-92.

Boudhrioua, N., Giampaoli, P., \& Bonazzi, C. (2003). Changes in aromatic components of banana during ripening and airdrying. Lebensmittel Wissenschaft Und Technologie Food Science and Technology, 36, 633-642.

Bourgeois, W., \& Stuetz, R. M. (2000). Measuring wastewater quality using a sensor array prospects for real-time monitoring. Water Science and Technology, 41, 107-112.

Bourgeois, W., \& Stuetz, R. M. (2002). Use of a chemical sensor array for detecting pollutants in domestic wastewater. Water Research, 36, 4505-4512.

Bourgeois, W., Gardey, G., Servieres, M., \& Stuetz, R. M. (2003a). A chemical sensor array based system for protecting wastewater treatment plants. Sensors and Actuators B Chemical, 91, 109-116.

Bourgeois, W., Hogben, P., Pike, A., \& Stuetz, R. M. (2003b). Development of a sensor array based measurement system for continuous monitoring of water and wastewater. Sensors and Actuators B Chemical, 88, 312-319.

Brattoli, M., de Gennaro, G., de Pinto, V., Loiotile, A. D., Lovascio, S., \& Penza, M. (2011). Odour detection methods: olfactometry and chemical sensors. Sensors, 11, 5290-5322.

Brattoli, M., Cisternino, E., De Gennaro, G., Giungato, P., Mazzone, A., Palmisani, J., \& Tutino, M. (2014). Gas chromatography analysis with olfactometric detection (GC-O): an innovative approach for chemical characterization of odor active volatile organic compounds (VOCs) emitted from a consumer product. Chemical Engineering Transactions, 40, 121-126.

Bulliner, E. A., Koziel, J. A., Cai, L., \& Wright, D. (2006). Characterization of livestock odors using steel plates, solid phase microextraction, and multidimensional-gas chromatography-mass spectrometry-olfactometry. Journal of the Air \& Waste Management Association, 56, 1391-1403.

Cadena, E., Colton, J., Sanchez, A., Font, X., \& Artola, A. (2009). A methodology to determine gaseous emissions in a composting plant. Waste Management, 29, 2799-2807.

Capelli, L., Sironi, S., Centola, P., del Rosso, R., \& Grande, M. (2008). Electronic noses for the continuous monitoring of odours from a wastewater treatment plant at specific receptors: focus on training methods. Sensors and Actuators B Chemical, 131, 53-62.

Capelli, L., Sironi, S., del Rosso, R., \& Centola, P. (2009). Predicting odour emissions from wastewater treatment plants by means of odour emission factors. Water Research, 43, 1977-1985.
Capelli, L., Sironi, S., Del Rosso, R., Centola, P., \& Bonati, S. (2010). Improvement of olfactometric measurement accuracy and repeatability by optimization of panel selection procedures. Water Science and Technology, 61, 1267-1278.

Capelli, L., Sironi, S., Del Rosso, R., Centola, P., Rossi, A., \& Austeri, C. (2011). Odour impact assessment in urban areas: case study of the city of Terni. Procedia Environmental Sciences, 4, 151-157.

Capelli, L., Sironi, S., Del Rosso, R., Bianchi, G., \& Davoli, E. (2012). Olfactory and toxic impact of industrial odour emissions. Water Science and Technology, 66, 1399-1406.

Capelli, L., Sironi, S., Del Rosso, R., \& Guillot, J. M. (2013). Measuring odours in the environment vs. dispersion modelling: a review. Atmospheric Environment, 79, 731-743.

Cheng, X. H., Peterkin, E., \& Narangajavana, K. (2007). Wastewater analysis for volatile organic sulfides using purge-and-trap with gas chromatography/mass spectrometry. Water Environment Research, 79, 442-446.

Davoli, E., Gangai, M. L., Morselli, L., \& Tonelli, D. (2003). Characterisation of odorants emissions from landfills by SPME and GC/MS. Chemosphere, 51, 357-368.

de Nevers, N. (2010). Air pollution control engineering: second edition. USA: Waveland Press, Inc.

Defoer, N., De Bo, I., Van Langenhove, H., Dewulf, J., \& Van Elst, T. (2002). Gas chromatography-mass spectrometry as a tool for estimating odour concentrations of biofilter effluents at aerobic composting and rendering plants. Journal of Chromatography A, 970, 259-273.

Delgado-Rodríguez, M., Ruiz-Montoya, M., Giraldez, I., López, R., Madejón, E., \& Díaz, M. J. (2012). Use of electronic nose and GC-MS in detection and monitoring some VOC. Atmospheric Environment, 51, 278-285.

Dentoni, L., Capelli, L., Sironi, S., Del Rosso, R., Zanetti, S., \& Della Torre, M. (2012). Development of an electronic nose for environmental odour monitoring. Sensors, 12, 1436314381.

Dewettinck, T., van Hege, K., \& Verstraete, W. (2001). The electronic nose as a rapid sensor for volatile compounds in treated domestic wastewater. Water Research, 35, 24752483.

Di Francesco, F., Lazzerini, B., Marcelloni, F., \& Pioggia, G. (2001). An electronic nose for odour annoyance assessment. Atmospheric Environment, 35, 1225-1234.

Dincer, F., \& Muezzinoglu, A. (2007). Odor determination at wastewater collection systems: olfactometry versus $\mathrm{H}_{2} \mathrm{~S}$ analyses. Clean Soil Air Water, 35, 565-570.

Dincer, F., Odabasi, M., \& Muezzinoglu, A. (2006). Chemical characterization of odorous gases at a landfill site by gas chromatography-mass spectrometry. Journal of Chromatography A, 1122, 222-229.

Dymerski, T., Chmiel, T., \& Wardencki, W. (2011). Invited review article: an odor-sensing system-powerful technique for foodstuff studies. Review of Scientific Instruments, 82, 111101.

Dymerski, T., Gebicki, J., Wardencki, W., \& Namiesnik, J. (2014). Application of an electronic nose instrument to fast classification of Polish honey types. Sensors, 14, 10709-10724.

Engg, D., \& College, I. (2013). Modern applications of electronic nose : a review. International Journal of Electrical and Computer Engineering, 3, 52-63. 
Escalas, A., Guadayol, J. M., Cortina, M., Rivera, J., \& Caixach, J. J. (2003). Time and space patterns of volatile organic compounds in a sewage treatment plant. Water Research, 37, 3913-3920.

Ferrari, G., Lablanquie, O., Cantagrel, R., Ledauphin, J., Payot, T., Fournier, N., \& Guichard, E. (2004). Determination of key odorant compounds in freshly distilled cognac using GC-O, GC-MS, and sensory evaluation. Journal of Agricultural and Food Chemistry, 52, 5670-5676.

Ferreira, V., Ortin, N., Escudero, A., Lopez, R., \& Cacho, J. (2002). Chemical characterization of the aroma of Grenache rose wines: aroma extract dilution analysis, quantitative determination, and sensory reconstitution studies. Journal of Agricultural and Food Chemistry, 50, 4048-4054.

Frank, D. C., Owen, C. M., \& Patterson, J. (2004). Solid phase microextraction (SPME) combined with gaschromatography and olfactometry-mass spectrometry for characterization of cheese aroma compounds. Lebensmittel Wissenschaft Und Technologie Food Science and Technology, 37, 139-154.

Fransses, E. A. M., Staatsen, B. A. M., \& Lebret, E. (2002). Assessing health consequences in an environmental impact assessment. The case of Amsterdam Airport Schiphol. Environmental Impact Assessment Review, 22, 633-653.

Gardner, J. W., \& Bartlett, P. N. (1994). A brief history of electronic noses. Sensors and Actuators B Chemical, 18, 211220.

Gebicki, J., Dymerski, T., \& Rutkowski, S. (2014a). Identification of odor of volatile organic compounds using classical sensory analysis and electronic nose technique. Environment Protection Engineering, 40, 103-116.

Gebicki, J., Dymerski, T., \& Namiesnik, J. (2014b). Monitoring of odour nuisance from landfill using electronic nose. Chemical Engineering Transactions, 40, 85-90.

Giuliani, S., Zarra, T., Nicolas, J., Naddeo, V., Belgiorno, V., \& Romain, A. C. (2012). An alternative approach of the e-nose training phase in odour impact assessment. Chemical Engineering Transactions, 30, 139-144.

Godayol, A., Alonso, M., Besalu, E., Sanchez, J. M., \& Antico, E. (2011). Odour-causing organic compounds in wastewater treatment plants: evaluation of headspace solid-phase microextraction as a concentration technique. Journal of Chromatography A, 1218, 4863-4868.

Gohlke, R. S., \& McLafferty, F. W. (1993). Early gas chromatography/mass spectrometry. Journal of the American Society for Mass Spectrometry, 4, 367-371.

Gostelow, P., Parsons, S. A., \& Stuetz, R. M. (2001). Odour measurements for sewage treatment works. Water Research, 35, 579-597.

Guillot, J. M. (2012). Odour measurement: focus on main remaining limits due to sampling. Chemical Engineering Transactions, 30, 295-300.

Guillot, J. M., Bilsen, I., Both, R., Hangartner, M., Kost, W. J., Kunz, W., Nicolas, J., Oxbol, A., Secanella, J., Van Belois, H., Van Elst, T., Van Harreveld, T., \& Milan, B. (2012). The future European standard to determine odour in ambient air by using field inspection. Water Science and Technology, 66, 1691-1698.

Guz, Ł., Łagód, G., Jaromin-Gleń, K., Suchorab, Z., Sobczuk, H., \& Bieganowski, A. (2015). Application of gas sensor arrays in assessment of wastewater purification effects. Sensors, 15 , $1-21$.

Henshaw, P., Nicell, J. A., \& Sikdar, A. (2006). Parameters for the assessment of odour impacts on communities. Atmospheric Environment, 40, 1016-1029.

Hobbs, P. J., Misselbrook, T. H., \& Pain, B. F. (1995). Assessment of odours from livestock wastes by a photoionization detector, an electronic nose, olfactometry and gas chromatography-mass spectrometry. Journal of Agricultural Engineering Research, 60, 137-144.

Hodgins, D. (1995). The development of an electronic 'nose' for industrial and environmental applications. Sensors and Actuators B Chemical, 27, 255-258.

Kleeberg, K. K., Liu, Y., Jans, M., Schlegelmilch, M., Streese, J., \& Stegmann, R. (2005). Development of a simple and sensitive method for the characterization of odorous waste gas emissions by means of solid-phase microextraction (SPME) and GC-MS/olfactometry. Waste Management, 25, 872-879.

Lazarova, V., Abed, B., Markovska, G., Dezenclos, T., \& Amara, A. (2013). Control of odour nuisance in urban areas: the efficiency and social acceptance of the application of masking agents. Water Science and Technology, 68, 614 621.

Le, H., Sivret, E. C., Parcsi, G., \& Stuetz, R. M. (2013). Stability of volatile sulfur compounds (VSCs) in sampling bags - impact of temperature. Water Science and Technology, 68, 18801887.

Littarru, P. (2007). Environmental odours assessment from waste treatment plants: dynamic olfactometry in combination with sensorial analysers "electronic noses". Waste Management, 27, 302-309.

Lo, Y. C. M., Koziel, J. A., Cai, L., Hoff, S. J., Jenks, W. S., \& Xin, H. (2008). Simultaneous chemical and sensory characterization of volatile organic compounds and semi-volatile organic compounds emitted from swine manure using solid phase microextraction and multidimensional gas-chromatographyolfactometry. Journal of Environmental Quality, 37, 521534.

Loriato, A. G., Salvador, N., Santos, J. M., Moreira, D. M., \& Reis, N. C. (2012). Odour - a vision on the existing regulation. Chemical Engineering Transactions, 30, 25-30.

Luginaah, I. N., Taylor, S. M., Elliott, S. J., \& Eyles, J. D. (2000). A longitudinal study of the health impacts of a petroleum refinery. Social Science \& Medicine, 50, 1155-1166.

Micone, P. G., \& Guy, C. (2007). Odour quantification by a sensor array: an application to landfill gas odours from two different municipal waste treatment works. Sensors and Actuators $B$ Chemical, 120, 628-637.

Munoz, R., Sivret, E. C., Parcsi, G., Lebrero, R., Wang, X., Suffet, I. H., \& Stuetz, R. M. (2010). Monitoring techniques for odour abatement assessment. Water Research, 44, 51295149 .

Naddeo, V., Zarra, T., Giuliani, S., \& Belgiorno, V. (2012). Odour impact assessment in industrial areas. Chemical Engineering Transactions, 30, 85-90.

Nagaraj, A., \& Sattler, M. (2005). Correlating emissions with time and temperature to predict worst-case emissions from open liquid area sources. Journal of the Air \& Waste Management Association, 55, 1077-1084.

Nagy, G. Z. (1991). The odor impact model. Journal of the Air \& Waste Management Association, 41, 1360-1362. 
Nake, A., Dubreuil, B., Raynaud, C., \& Talou, T. (2005). Outdoor in situ monitoring of volatile emissions from wastewater treatment plants with two portable technologies of electronic noses. Sensors and Actuators B Chemical, 106, 36-39.

Nicell, J. A. (2009). Assessment and regulation of odour impacts. Atmospheric Environment, 43, 196-206.

Nicolas, J., \& Romain, A. C. (2004). Establishing the limit of detection and the resolution limits of odourous sources in the environment for an array of metal oxide gas sensors. Sensors and Actuators B Chemical, 99, 384-392.

Onkal-Engin, G., Demir, I., \& Engin, S. N. (2005). Determination of the relationship between sewage odour and BOD by neural networks. Environmental Modelling \& Software, 20, 843850.

Pandey, S. K., \& Kim, K. H. (2009). Comparative analysis of odorous volatile organic compounds between direct injection and solid phase microextraction: development and validation of a gas chromatography-mass spectrometry-based methodology. Journal of Chromatography A, 1216, 5436-5444.

Patel, H. K. (2014). The electronic nose: artificial olfaction technology. India: Springer.

Plutowska, B., \& Wardencki, W. (2008). Application of gas chromatography-olfactometry $(\mathrm{GC}-\mathrm{O})$ in analysis and quality assessment of alcoholic beverages - a review. Food Chemistry, 107, 449-463.

Rajbansi, B., Sarkar, U., \& Hobbs, S. E. (2014). Hazardous odor markers from sewage wastewater: a step towards simultaneous assessment, dearomatization and removal. Journal of the Taiwan Institute of Chemical Engineers, 45, 1549-1557.

Ranau, R., Kleeberg, K. K., Schlegelmilch, M., Streese, J., Stegmann, R., \& Steinhart, H. (2005). Analytical determination of the suitability of different processes for the treatment of odorous waste gas. Waste Management, 25, 908-916.

Ras, M. R., Borrull, F., \& Marce, R. M. (2008). Determination of volatile organic sulfur compounds in the air at sewage management areas by thermal desorption and gas chromatography-mass spectrometry. Talanta, 74, 562-569.

Rock, F., Barsan, N., \& Weimar, U. (2008). Electronic nose: current status and future trends. Chemical Reviews, 108, $705-725$.

Romain, A. C., Godefroid, D., \& Nicolas, J. (2005). Monitoring the exhaust air of a compost pile with an e-nose and comparison with GC-MS data. Sensors and Actuators B Chemical, 106, 317-324.

Rosenfeld, P., Grey, M., \& Sellew, P. (2004). Measurement of biosolids compost odor emissions from a windrow, static pile, and biofilter. Water Environment Research, 76, 310315.

Rosenkranz, H. S., \& Cunningham, A. R. (2003). Environmental odors and health hazards. Science of the Total Environment, 313, 15-24.

Sankaran, S., Khot, L. R., \& Panigrahi, S. (2012). Biology and applications of olfactory sensing system: a review. Sensors and Actuators B Chemical, 171, 1-17.

Schwarzenbach, R., Gschwend, P., \& Imboden, D. (2003). Environmental organic chemistry (2nd ed.). New York: Wiley.

Sheng, Y., Chen, F., Wang, X., Sheng, G., \& Fu, J. (2008). Odorous volatile organic sulfides in wastewater treatment plants in Guangzhou, China. Water Environment Research, 80, 324-330.
Sironi, S., Capelli, L., Centola, P., Del Rosso, R., \& Pierucci, S. (2010). Odour impact assessment by means of dynamic olfactometry, dispersion modelling and social participation. Atmospheric Environment, 44, 354-360.

Smeets, M. A. M., Bulsing, P. J., van Rooden, S., Steinmann, R., de Ru, J. A., Ogink, N. W. M., van Thriel, C., \& Dalton, P. H. (2007). Odor and irritation thresholds for ammonia: a comparison between static and dynamic olfactometry. Chemical Senses, 32, 11-20.

Sohn, J. H., Smith, R. J., \& Yoong, E. (2006). Process studies of odour emissions from effluent ponds using machine-based odour measurements. Atmospheric Environment, 40, 1230 1241.

Sohn, J. H., Hudson, N., Gallagher, E., Dunlop, M., Zeller, L., \& Atzeni, M. (2008). Implementation of an electronic nose for continuous odour monitoring in a poultry shed. Sensors and Actuators B Chemical, 133, 60-69.

Sówka, I. (2010). Assessment of air quality in terms of odor according to selected European guidelines: grid and plume measurements. Environment Protection Engineering, 36, 133-141.

Sówka, I., Skrętowicz, M., Szklarczyk, M., \& Zwoździak, J. (2011). Evaluation of nuisance of odour from food industry. Environment Protection Engineering, 37, 5-12.

Staley, B. F., Xu, F., Cowie, S. J., Barlaz, M. A., \& Hater, G. R. (2006). Release of trace organic compounds during the decomposition of municipal solid waste components. Environmental Science \& Technology, 40, 5984-5991.

Stuetz, R. M., \& Frechen, F. B. (2001). Odours in wastewater treatment: measurement, modeling and control. London: IWA Publishing.

Stuetz, R. M., Engin, G., \& Fenner, R. A. (1998). Sewage odour measurements using a sensory panel and an electronic nose. Water Science and Technology, 38, 331-335.

Stuetz, R. M., Fenner, R. A., \& Engin, G. (1999a). Characterisation of wastewater using an electronic nose. Water Research, 33, 442-452.

Stuetz, R. M., Fenner, R. A., \& Engin, G. (1999b). Assessment of odours from sewage treatment works by an electronic nose, $\mathrm{H}_{2} \mathrm{~S}$ analysis and olfactometry. Water Research, 33, 453461.

Su, Y. C., Chang, C. C., \& Wang, J. L. (2008). Construction of an automated gas chromatography/mass spectrometry system for the analysis of ambient volatile organic compounds with on-line internal standard calibration. Journal of Chromatography A, 1201, 134-140.

Suffet, I. H., \& Rosenfeld, P. E. (2007). The anatomy of odour wheels for odours of drinking water, wastewater, compost and the urban environment. Water Science and Technology, 55, 335-344.

Suffet, I. H., Burlingame, G. A., Rosenfeld, P. E., \& Bruchet, A. (2004). The value of an odor-quality-wheel classification scheme for wastewater treatment plants. Water Science and Technology, 50, 25-32.

Szczurek, A., \& Maciejewska, M. (2005). Relationship between odour intensity assessed by human assessor and TGS sensor array response. Sensors and Actuators B Chemical, 106, 1319.

Turkmen, M., Dentel, S. K., Chiu, P. C., \& Hepner, S. (2004). Analysis of sulfur and nitrogen odorants using solid-phase 
microextraction and GC-MS. Water Science and Technology, 50, 115-120.

van Ruth, S. M. (2001). Methods for gas chromatographyolfactometry: a review. Biomolecular Engineering, 17, 121-128.

Vergara, A., Fonollosa, J., Mahiques, J., Trincavelli, M., Rulkov, N., \& Huerta, R. (2013). On the performance of gas sensor arrays in open sampling systems using inhibitory support vector machines. Sensors and Actuators B Chemical, 185, 462-477.

Wilson, A. D., \& Baietto, M. (2009). Applications and advances in electronic-nose technologies. Sensors, 9, 5099-5148.

Woolfenden, E. (2010a). Sorbent-based sampling methods for volatile and semi-volatile organic compounds in air. Part 1: sorbent-based air monitoring options. Journal of Chromatography A, 1217, 2674-2684.

Woolfenden, E. (2010b). Sorbent-based sampling methods for volatile and semi-volatile organic compounds in air. Part 2: sorbent selection and other aspects of optimizing air monitoring methods. Journal of Chromatography A, 1217, 26852694.

Wu, B. Z., Feng, T. Z., Sree, U., Chiu, K. H., \& Lo, J. G. (2006). Sampling and analysis of volatile organics emitted from wastewater treatment plant and drain system of an industrial science park. Analytica Chimica Acta, 576, 100-111.

Zarra, T., Naddeo, V., \& Belgiorno, V. (2008a). Measurement, management and control of odours in wastewater treatment plants by portable GC-MS. Chemical Engineering Transactions, 15, 63-70.

Zarra, T., Naddeo, V., Belgiorno, V., Reiser, M., \& Kranert, M. (2008b). Odour monitoring of small wastewater treatment plant located in sensitive environment. Water Science and Technology, 58, 89-94.

Zarra, T., Naddeo, V., Belgiorno, V., Reiser, M., \& Kranert, M. (2009). Instrumental characterization of odour: a combination of olfactory and analytical methods. Water Science and Technology, 59, 1603-1609.

Zarra, T., Reiser, M., Naddeo, V., Belgiorno, V., \& Kranert, M. (2012). A comparative and critical evaluation of different sampling materials in the measurement of odour concentration by dynamic olfactometry. Chemical Engineering Transactions, 30, 307-312.

Zarra, T., Reiser, M., Naddeo, V., Belgiorno, V., \& Kranert, M. (2014). Odour emissions characterization from wastewater treatment plants by different measurement methods. Chemical Engineering Transactions, 40, 37-42.

Zhang, S., Cai, L., Koziel, J. A., Hoff, S. J., Schmidt, D. R., Clanton, C. J., Jacobson, L. D., Parker, D. B., \& Heber, A. J. (2010). Field air sampling and simultaneous chemical and sensory analysis of livestock odorants with sorbent tubes and GC-MS/olfactometry. Sensors and Actuators B Chemical, 146, 427-432. 